\title{
"The Spirit of the Pioneers"
}

By L. J. LUBINIECKI, Sturgis, Sask.

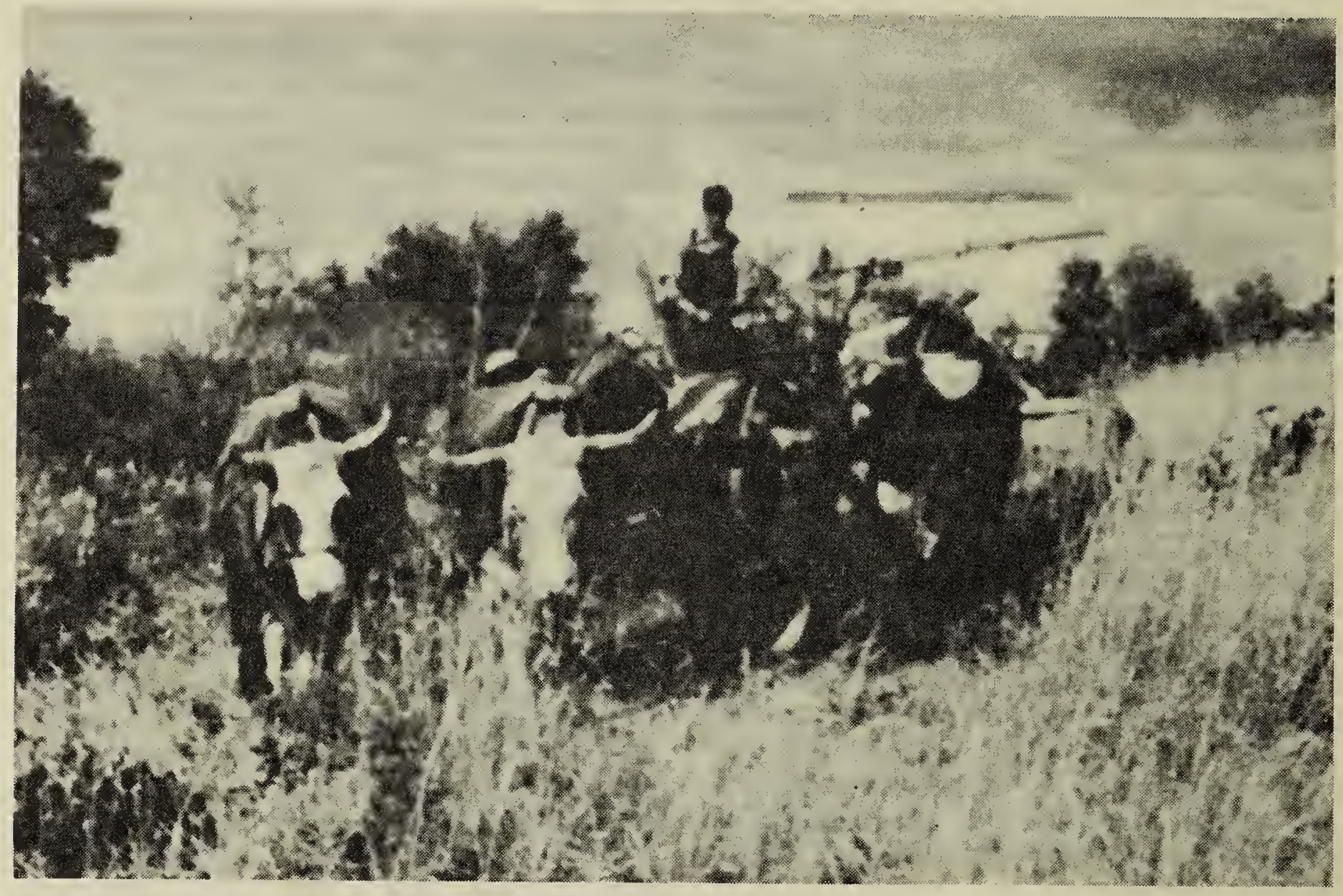

I heard of this farmer living 16 miles north of here who was doing all his farm work with a yoke of oxen, so took a trip up there and was lucky as he was just going to take the oxen out to start the first round on his grain. Thought this was so unusual, as most other farmers have gone into mechanized farming or at least were using horses if their farm was small.

Behind one of the oxen can be seen the head of the farmer's small girl (about 12 years old). She has a whip in her hand and uses it whenever anyone of the oxen lags behind.

Camera used: Kodak vest pocket camera No. 127. Film: Kodak super XX Pan at about f/11. Fixed speed at about $1 / 25$ sec. Filter: Red Shot at 90 deg. to sun. Enlarged on OPAL C.

\section{LEARNING}

We study first the pictures and the print,

And then go forth to find a painted bunting,

Or redstart, to identify by dint

Of constant watching and persistant hunting;

But if sometimes we meet a mountaineer,

Who, with one dart of quick and practiced eye,

Can name whatever bird may disappear
Before we see it, we are oddly shy.

Booklearning is of course to be preferred

To none, but there's a difference in the look

Of those who know the book without the bird

And those who know the bird without the book.

Jane Merchant

in the Glen Ridge, N.J., Paper.

South Dakota Bird Notes 